\title{
Therapeutic itinerary of families of children with special health needs*
}

\author{
Itinerário terapêutico de famílias de crianças com necessidades especiais de saúde
}

Roberta de Oliveira Luz ${ }^{1}$, Greice Machado Pieszak ${ }^{1}$, Andrea Moreira Arrué2, Giovana Calcagno Gomes ${ }^{3}$, Eliane Tatsch Neves ${ }^{4}$, Andressa Peripolli Rodrigues ${ }^{5}$

Objective: to describe the therapeutic itinerary of families of children with special health needs. Methods: this is a qualitative study carried out at the household of 14 families enrolled in primary health care. Results: Participant families reported negative feelings with the discovery of the diagnosis, which intensified with the absence of professional guidance. They faced difficulties of access by the Unified Health System, having to seek the private service to care for their children and fragility regarding their own rights. Conclusion: in the therapeutic itinerary of the families of children with special health needs, they suffer constant pilgrimages through health care networks seeking assistance and resolution.

Descriptors: Disabled Children; Family; Pediatric Nursing; Health Services Accessibility.

Objetivo: descrever o itinerário terapêutico de famílias de crianças com necessidades especiais de saúde. Métodos: estudo qualitativo, realizado no domicílio de 14 famílias cadastradas na atenção primária à saúde. Resultados: as famílias participantes relataram sentimentos negativos com a descoberta do diagnóstico, os quais se intensificaram com a ausência de orientações de profissionais. Percorreram caminhos, enfrentaram dificuldades de acesso pelo Sistema Único de Saúde, tendo que buscar o serviço privado para assistência aos(às) filhos(as), e fragilidade com relação aos próprios direitos. Conclusão: no itinerário terapêutico das famílias de crianças com necessidades especiais de saúde, estas sofrem constantes peregrinações pelas redes de atenção à saúde em busca de assistência e resolutividade.

Descritores: Crianças com Deficiência; Família; Enfermagem Pediátrica; Acesso aos Serviços de Saúde.

\footnotetext{
*Extracted from the Term Paper titled "Itinerário terapêutico das famílias de crianças com necessidades especiais de saúde", Universidade Regional Integrada do Alto Uruguai e das Missões, 2017.

${ }^{1}$ Universidade Regional do Alto Uruguai e das Missões. Santiago, RS, Brazil.

${ }^{2}$ Fundação Oswaldo Cruz. Rio de Janeiro, RJ, Brazil.

${ }^{3}$ Universidade Federal do Rio Grande. Rio Grande, RS, Brazil.

${ }^{4}$ Universidade Federal de Santa Maria. Santa Maria, RS, Brazil.

${ }^{5}$ Instituto Federal de Educação, Ciência e Tecnologia Farroupilha. Santo Ângelo, RS, Brazil.

Corresponding author: Roberta de Oliveira Luz

Rua Júlio de Castilhos, 644. Apto. 203. CEP: 95703-064 - Bento Gonçalves, RS, Brazil. E-mail: robertaluz95@gmail.com
} 


\section{Introduction}

In Brazil, the implementation of child health policies has tried to reduce child mortality rates through comprehensive care and with the purpose of linking the family in this process, deconstructing the disease-centered model ${ }^{(1)}$. The National Policy for Integral Care to Children's Health that promotes integrality in the health care of children stands out among the governmental actions with special attention to families that present greater vulnerability, reducing infant mortality due to preventable causes and guaranteeing conditions suitable for growth and development. In the last decades, the profile of childhood in Brazil has changed with the emergence of chronic diseases related to perinatal conditions ${ }^{(2)}$.

However, the illness of the child is an unexpected process for any family that many times causes feelings of denial, guilt, but mainly fear, pain and suffering. In this context, there are children with special health needs, and Brazil they were classified according to the demands of care: development care, which includes those with muscular neuromotor dysfunction, functional and incapacitating limitations; technological care, which refer to children using life-sustaining devices such as gastrostomy, tracheostomy, colostomy, among others; medicine care, those who has continuous use of drugs; children who need adaptive technologies in day-to-day care and activities of daily living; mixed care, where there is a combination of one or more demands, excluding technological care ${ }^{(3)}$.

Caring for a child with specific demands requires articulation between people and places inserted in a social network ${ }^{(4)}$. Thus, health care networks must provide integral, quality and resolute care to families. An organized primary health care service is essential to coordinate care and to be responsible for the flow of patients, to optimize the reference and counterreferral services ${ }^{(5)}$, which are necessary for the followup of these children.

The term Therapeutic Itinerary is used to des- cribe the path traveled by people in search of health services to solve needs. During this trajectory, individuals draw plans and actions to deal with the illness. In this sense, it is essential to know the itineraries traveled by families of children who need special healthcare in search of resolution, since it is an important tool for the improvement of health services ${ }^{(6)}$.

Therefore, it is important to highlight that the studies on therapeutic itineraries in Brazil are recent and little explored by researchers and managers, besides the focus of interest is the patient's perception about disease and treatment, there are few studies that deepen access and use of the services, considering the context of the patient ${ }^{(7)}$. Thus, it is intended to contribute to improving the quality of care offered to children with special health needs by health care networks, strengthening social networks and support and reducing the risks and vulnerability of this people.

The question of the study is: what is the path traveled by families of children with special health needs and how are they supported by health care networks? To answer the question, the objective of the study was to describe the therapeutic itinerary of families of children with special health needs.

\section{Methods}

This is a qualitative study, carried out at the household of families of children with demands, belonging to the Family Health Strategies of a municipality in the interior of Rio Grande do Sul, Brazil. The inclusion criteria were: to have a child with special health needs in the family, to be aware of the demands of care and the paths covered for access to the health services. This last criterion was established through the previous dialogue with the family members, who should inform briefly the path taken. The exclusion criterion was families that after two attempts to access the home was not found.

Data were collected from August to October 2017, with three Family Health Strategies being dra- 
wn from the 11 in the municipality. The option for the draw was due to the fact that the units do not have records that specify children with special health needs, choosing a random selection of health units.

The study participants were 14 families of children with special health needs. The ideal number of informants should represent the coherence with the object of study and the multiple dimensions of the research, since the quantification of the number of participants is defined by the recurrence of the phenomenon in the sample ${ }^{(8)}$, making this number of families representative of the studied population.

Data collection was started with the triage of children with special health needs, Children with Special Health Care Needs Screener (CSHCN Screener) ${ }^{(9)}$, to pre-select the participants. The instrument, recently translated and adapted to Brazilian reality, is composed of five structured questions, which must be answered by those who provide care to children, whether or not they are family members, allowing the identification and evaluation of the care demands of each child, according to three domains: dependence of medications prescribed for a certain clinical condition, use of health services above the normal or routine, and the presence of functional limitations.

The instrument was applied to the patients of the three Family Health Strategies that were awaiting medical or childcare consultations and those who arrived by spontaneous demand to identify the existence of a child with special health needs in the family. When it was confirmed, a home visit was scheduled for data collection. After selecting and accepting to participate in the study, a semi-structured interview was conducted in two parts and performed at the children's home, with the presence of the main caregiver and other members, while they were in the place.

The first part of the interview had questions to characterize participants (religious orientation, marital status, living conditions, family income, school level, and childbirth data). In the second part, there were questions about the child's birth, the routine changes in the family after the diagnosis, the path taken in search of care, and the services and professionals who supported them during this phase. The interviews were carried out by the researcher, with an average duration of fifty minutes and the interviews were recorded when authorized by the participants, and then they were fully transcribed.

For the data analysis, the Thematic Content Analysis was applied, in which the first stage is known as pre-analysis, which consisted in the separation of the documents to be analyzed, floating reading and resumption of the objectives. The material exploration was then performed, in which the data were classified according to words and most significant expressions, aimed to reach the central idea of the lines. Finally, the treatment of the obtained results and interpretation was performed from the analysis of the raw data, allowing inferences and interpretations ${ }^{(10)}$.

To identify and preserve the anonymity of the study participants, an alphanumeric coding was used to classify them by the initial " $F$ " of the word Family, followed by ordinal numbers, according to the sequence in which the interviews were recorded and transcribed.

The study complied with the formal requirements contained in the national and international regulations of research involving human beings, according to Resolution 466/2012 and it was approved by the Ethics and Research Committee, according to opinion number 2,198,579 and Certificate of Presentation for Appraisal Ethics number 71343517.9.0000.5353.

\section{Results}

Among 14 families interviewed, 15 children with special health needs were identified, since two were from the same family. Ten of them were male and five were female. The ages of children ranged from two to 12 years old.

With the use of the CSHCN Screener instrument, it was possible to classify these children with 
special health needs by the care demands. Six children had developmental care demands, two had medicine care demands and six had mixed care demands, linking developmental and medicine demand.

Regarding the composition of the families participating in the study, nine had only the mother of the child present, considered only her and the child as a "Family". In one interview, the father was the only caregiver/responsible by the child. The others had other people in the family composition.

In the interviews, both parents participated, one mother and the neighbor and the other the mother and two aunts, and people whose main responsible considered like a member of the family. Also, four of these children had another family member with some special need.

As for the education of the 19 respondents, six had incomplete elementary school, one had complete elementary school, two had incomplete high school, nine had complete high school and only one had complete higher education. As for religion, seven families were evangelical, five Catholic and two with undefined religion.

Data analysis enabled the creation of two categories: Therapeutic itinerary of families of children with special health needs in search of resolution; and Difficulty of access to health care networks and fragility of care in primary health care.

\section{Therapeutic itinerary of families of children with special health needs in search of resolution}

The therapeutic itinerary of the families of children with special health needs aims at the resolution of the problem presented by the child. In the therapeutic itineraries, the health care networks were mentioned. The families participating in the study went through services in search of resolution for the care of the children. We went to the pediatrician through the Unified Health System, I took him and he examined him, but he did not want to give me the answer there, he did not tell me, he said he thought it might be Down Syndrome but that he would confirm through the exam, to (name of the city), I went to the Secretary of Health to ask for the consultation, and we did not, well in the end I had to pay a particular one (F7). The pediatrician (name of the city) was very good, he sent me to the endocrine, in cardiology, he told me to look for the Association of Parents and Friends of the Exceptional (F8).

They reported that primary health care was resolutive and they felt safe with the assistance offered by the service, but some tried to get referrals to another network. She rarely gets sick, I look for the center (Family Health Strategy) and I get anything I need, including referral to the pediatrician (F3). Here at the health center what he (doctor) cannot solve, he forwards you (F4). During the day here in the strategy (Family Health Strategy) and at the end of the week, I take on duty at the hospital (F6). I go here to the center (Family Health Strategy), because it is difficult to get it even in the private area (F15). Then, after she did the surgery, the ear specialist from (name of the city) who referred me again to the accompaniment with the speech therapist and the psychologist, I got these appointments with the nurse here of the center (Family Health Strategy) F3).

However, faced with constant pilgrimages and difficulties of displacements and schedules for consultations by the Unified Health System, families sought the private system. In some places, we had a lot of difficulty in the Unified Health System, in (name of the city), we could not make an appointment any more, the driver did not want to make an appointment for us anymore, so well, in the end, we had to go there alone to make the appointment, then take him, then we decided to make the health insurance here, as he is no longer a child, the neurologist does not have to be a pediatrician (F6). It was all here in (name of the city), had in (name of another city) by the Unified Health System, but for us it becomes more difficult, it gets more expensive than paying here, so when I have to take him, I save a little and paid the consultation because for me it becomes easier (F9).

The statements show that some families still have a preference for care in tertiary care for children, due to the ease of getting assistance, even if it does not continue. At the hospital, because it's faster. In the Family Health Strategy, sometimes it takes a while, you have to make an appointment (F2). In the hospital emergency room. But if it's daylight I'll take the pediatrician (F5). When you need it, it's there at the hospital 
emergency room, when it's serious, or I look for the pediatrician (F7). We look at the hospital first, if it is such an emergency, at the hospital first aid room (F8). When it's the end of the week, in the emergency room, because it's the place it has (F10). On duty (hospital emergency room), or in the private clinic by the insurance (F13/14).

There are those who have a preference and opt for private service assistance in private clinics. Now it's his doctor, but when he did not have this doctor he was always at the hospital's emergency room (F9). Depends on what he feels usually everything is in (name of city), but if it is necessary, I take it here at the pediatrician (F12).

With this, the persistence of the families in search of the resolution of the children's needs are stand out, even in situations that made the pilgrimage by the health services constant.

\section{Difficulty of access to health care networks and fragility of care in primary health care}

The data collected showed that despite the search for care, there is a lack of care by the health care networks, in the care of the families of children with special health needs. In this context, it was verified the difficulty of professionals in the moment of informing the diagnosis to the relatives, leaving them unassisted, vulnerable to seeking guidelines alone. The doctor told me that it could be Down syndrome, but he had to take an exam, he sent me to (city name) to take the exam there and we went and did and it appeared that it was, it was there that I was given the diagnosis. I was like this, my God: what is this?! I had no knowledge, I did not know what was right, so I went searching the internet to see what it was and I freaked out even more (F7). I think, that day the doctor was not very well, we did not like the way he said, he said "This guy (autistic) is autistic", very straight (F13/14).

Furthermore, some reports have demonstrated the lack of credibility of families for the care of children with special health needs in primary health care, including evidencing the absence of an active search of the health team for the family. No, because there in the Family Health Strategy we will not even go, only when it's a little something, little flu (F1). Not here in the Family Health Strategy! Here,
I have no faith (F5). Here in Family Health Strategy, there are general medicine professionals, there is no pediatrician (F10). Very little we go there, almost nothing, until when the (child's name) was born, my community health agent was on leave, so all that time, everything we went through, the neighborhood knew, everyone was talking, but nobody from the health area came here (F11).

Also, when questioned about receiving some childcare benefit/assistance, only eight received the benefit, one family had no knowledge of this right, three were seeking legal redress and three did not fit the criteria for that guarantee.

The families were not aware or they were faulty about the children's rights, also showing the lack of guidance of professionals who could be the mediators to guarantee the rights of the child. In many cases, families knew about this right late by other people. I knew that she had a right when she was about two years old. I was told by my aunt who told me that my cousin had some acquaintances who had a child with the same problem (F4). Ah! What I fought, God forbid. I fought, I fought, I had to take a test that cost 520.00 reais to prove that she had a disability and I did not have that money to do it (F5). It was a neighbor who indicated when we lived there in the interior, so we went to see, he was already about three years I think (F6). I was told by another lady who lives nearby; her daughter has the same problem so she told me that he had right because he would have trouble working (F12).

Different from this reality, some families had no difficulty in obtaining the aid, due to the support and guidance of other professionals, or even the same ones have knowledge of the child's case. I went in (name of the city) because as he was doing treatment there in (name of the city), the school had a lawyer, so she gave me some information and I searched there, it was very fast (F6). He did the exams, they were all paid, I showed up at the National Social Security Institute, everyone there already knew his case, they had his records, the doctor did the triage, all right, he released us immediately. It was quick because they were already aware of everything, that he was already treated with the doctors here, the pediatricians (F12). I did not know, I learned through the Association of parents and friends of the exceptional, the first time I went there with him, the social worker there communicated to me, but I only managed it when I went to justice (F7). 
It is also worth noting the family members' difficulties for the rights of these children, since, in most cases, they have to find justice. I had to go to court to get it, because at the time I did not even work, and I did not have anything and the National Social Security Institute denied me and then I went through justice and got it, it was almost two years old (F7). It was not very easy to get it, at first it was denied, so we appealed to a lawyer and was denied again, but then we went back and got it. He was about two years old already (F8). We still cannot, but we're trying. First I tried normal, but it was refused, now I hired a lawyer, I entered with the appeal, I forwarded it, now it is in the hands of the judge (F15).

Thus, the importance of health professionals being qualified to provide assistance and adequately inform these families was emphasized to seek a better quality of life for families and their children.

\section{Discussion}

Based on the study, some limitations were observed, such as the difficulty of identifying children with special health needs in the Family Health Strategies, due to the low demand for service and restricted participation of few family members in the interviews. Despite this, the study contributes to care practice to improve the provision of care to the families of children with special health needs, through the strengthening, effectiveness, and quality of care provided by health care networks.

Therefore, knowing and understanding the therapeutic itinerary of families using public health services allows recognizing the confrontations, facilities, and barriers found by them when searching for a diagnosis and the implementation of a therapeutic plan that is consolidated by a multi-professional team and the needs of these patients ${ }^{(11)}$.

In this context, there are health care networks that allow the provision of continuous and integral care coordinated by the primary health care, in a humanized and safe way. However, the families of these children still face constant pilgrimages in the search for access and resolution of the health services, due to numerous failures in the organization and structure of health care networks that fail to meet the real needs of families and sometimes the family is discouraged from seeking care in primary health care ${ }^{(12)}$.

From this perspective, families end up searching for the places with the greatest technological density to provide assistance to their children due to the primary level services, evidencing the difficulties of access for continuity to the treatment of children with special health needs in the post-hospital dischar$\mathrm{ge}^{(13)}$. The absence of an effective referral and counter-referral system hampers the trajectory of these relatives/caregivers, as well as harming the principles of integrality and universality, as well as the rights of patients for the Unified Health System ${ }^{(14)}$.

The study showed that the primary health care services need to be strengthened as a gateway for the population's assistance, as well as an effective referral and counter-referral service that would enable, after hospital care, continuity of care in the respective Family Health Strategies.

However, study data highlighted the challenges for continuity of child care in a chronic condition in primary health care, due to the demand for care superior to the possibilities of the place. This is due to the reduced number of professionals in the health units, the fragmented work of the health teams, the inefficiency of referral and counter-referral, the difficulty of working between the health care networks, the insufficient logistical system of transportation and the lack of inputs and technologies ${ }^{(15)}$.

Also, the work of the multi-professional team is necessary for the care to children with special health needs because they present several demands related to the rehabilitation and reduction of complications arising from chronic conditions. The multi-professional team can encourage the family to identify a social support network for the care required by children with special health needs ${ }^{(16)}$.

It was also identified that the difficulties faced by families are often due to the lack of communica- 
tion and support of health professionals. Therefore, it is important for professionals to dialogue with the family, to offer effective guidance, a sensitive listener to the doubts since the discovery of the special need has an impact on the family member's life and can be diminished through the support of information ${ }^{(17)}$.

Thus, the process of permanent education in the Family Health Strategy is indispensable so they can carry out assistance actions in an integral and quality way, inserting the families in this care ${ }^{(18)}$. To do this, it is possible to train caregivers to perform necessary procedures, provide information about their rights, and provide emotional support to the family that also needs care ${ }^{(19)}$.

However, the mode of organization, the scarcity of structure and resources reflect in the fragmented way in which care for children with chronic conditions and families is being carried out in health care networks, for the symptoms and not to the singularities of their conditions ${ }^{(15)}$. Thus, these issues need to be evaluated and modified by professionals, patients and managers, so the primary health care is configured as an efficient space to meet the real health needs of the patients.

As for the rights of these children, there are laws that ensure them and favor people who have some chronic diseases. However, many families are not aware or have deficient information about the topic, and it is necessary that existing public policies be effectively implemented and that they cover all peo$\mathrm{ple}^{(15)}$.

Also, the frailties in the family counseling process by professionals working in the health care network services directly influence the search for rights, since some of the families surveyed were unaware of the existence of public policies in favor of people with chronic diseases. This situation becomes an obstacle for these families to achieve empowerment and to enjoy rights ${ }^{(20)}$, requiring the support of health professionals so these families have knowledge about the- se rights that will contribute to improvements in the quality of life.

\section{Conclusion}

In the therapeutic itinerary of families of children with special health needs, they suffer constant pilgrimages through health care networks seeking assistance and resolution. Socioeconomic difficulties, fragile access to these services and the compromised bond between families and professionals interfered in their support when searching for qualified care.

\section{Acknowledgments}

To the Universidade Regional Integrada do Alto Uruguai e das Missões for the opportunity and support for the accomplishment of this article.

\section{Colaborations}

Luz RO and Pieszak GM contributed to the project design, data analysis and article writing. Arrué AM, Gomes GC, Neves ET and Rodrigues AP assisted in the critical review of the intellectual content and final approval of the version to be published.

\section{References}

1. Araújo JP, Silva RMM, Collet N, Neves ET, Toso BRGO, Vieira CS. History of the child's health: conquers, policies and perspectives. Rev Bras Enferm. 2016; 67(6):1000-7. doi: http://dx.doi. org/10.1590/0034-7167.2014670620

2. Ministério da Saúde (BR). Política Nacional de Atenção Integral à saúde da criança. Brasília: Ministério da Saúde; 2015.

3. Cabral IE, Moraes JRMM. Family caregivers articulating the social network of a child with special health care needs. Rev Bras Enferm. 2015; 68(6):769-76. doi: dx.doi.org/10.1590/00347167.2015680612i 
4. Neves ET, Cabral IE, Silveira A. Family network of children with special health needs: implications for Nursing. Rev Latino-Am Enfermagem. 2013; 21(2):562-70. doi: http://dx.doi.org/10.1590/ S0104-11692013000200013

5. Conselho Nacional de Secretários de Saúde (BR). A atenção primária e as Redes de Atenção à Saúde. Brasília: CONASS; 2015.

6. Barbieri MC, Broekman GVDZ, Souza ROD, Lima RAG, Wernet M, Dupas G. Support network for families of children and adolescents with visual impairment: strengths and weaknesses. Ciênc Saúde Coletiva. 2016; 21(10):3213-22. doi: dx.doi. org/10.1590/1413-812320152110.19562016

7. Cabral ALLV, Martinez-Hemáez A, Andrade EIG, Cherchiglia ML. Itinerários terapêuticos: o estado da arte da produção científica no Brasil. Ciênc Saúde Coletiva. 2011; 16(11):4433-42. doi: dx.doi. org/10.1590/S1413-81232011001200016

8. Minayo MCS. Amostragem e saturação em pesquisa qualitativa: consensos e controvérsias. Rev Pesq Qual [Internet]. 2017 [citado 2018 dez. 13]; 5(7):1-12. Disponível em: https://editora. sepq.org.br/index.php/rpq/article/view/82/59

9. Arrué AM, Neves ET, Magnago TSBS, Cabral IE, Gama SGN, Hökerberg YHM. Translation and adaptation of the Children with Special Health Care Needs Screener to Brazilian Portuguese. Cad Saúde Pública. 2016; 32(6):e00130215. doi: http://dx.doi.org/10.1590/0102-311X00130215

10. Macedo EC, Silva LR, Paiva MS, Ramos MNP. Burden and quality of life of mothers of children and adolescents with chronic illnesses: an integrative review. Rev Latino-Am Enfermagem. 2015; 23(4):769-77. doi: http://dx.doi. org/10.1590/0104-1169.0196.2613.

11. Morais AC, Cohim ACOS, Almeida CR, Lima KDF. Therapeutic itinerary of children's mothers after the Kangaroo Method. Ciênc Cuid Saúde. 2017; 16(2). doi: http://dx.doi.org/10.4025/ cienccuidsaude.v16i2.35994

12. Mendes EV. Entrevista: a abordagem das condições crônicas pelo Sistema Único de Saúde. Ciênc Saúde Coletiva. 2018; 23(2):431-6. doi: http://dx.doi. org/10.1590/1413-81232018232.16152017
13. Pinto MMPS, Coutinho SED, Collet N. Chronic illness in childhood and attention from health services. Ciênc Cuid Saúde. 2016; 15(3):498-506. doi: http://dx.doi.org/10.4025/cienccuidsaude. v15i3.28575

14. Brondani JE, Leal FZ, Potter C, Silva RM, Noal HC, Perrando MS. Desafios da referência e contrarreferência na atenção em saúde na perspectiva dos trabalhadores. Cogitare Enferm. 2016; 21(1):1-8. doi: http://dx.doi.org/10.5380/ ce.v21i1.43350

15. Duarte ED, Silva KL, Tavares TS, Nishimoto CLJ, Silva PM, Sena RR. Care of children with a chronic condition in primary care: challenges to the healthcare model. Texto Contexto Enferm. 2015; 24(4):1009-17. doi: dx.doi.org/10.1590/01040707201500003040014

16. Barbosa TA, Reis KMN, Lomba GO, Alves GV, Braga PP. Support network and social support for children with special health care need. Rev Rene. 2016; 17(1):60-6. doi: http://dx.doi. org/10.15253/2175-6783.2016000100009

17. Cerqueira MMF, Alves RO, Aguiar MGG. Experiences in the therapeutic itineraries of mothers of children with intellectual disabilities. Ciênc Saúde Coletiva.2016; 21(10):3223-32. doi: http://dx.doi. org/10.1590/1413-812320152110.17242016

18. Belmiro SSDR, Miranda FAN, Moura IBL, Carvalho SR, Monteiro AI. Atuação da equipe de enfermagem na assistência à criança com deficiência na atenção primária à saúde. Rev Enferm UFPE on line [Internet]. 2017 [citado $2018 \mathrm{dez}$ 13]; 11(Suppl.4):1679-86. Disponível em: https:// periodicos.ufpe.br/revistas/revistaenfermagem/ article/viewFile/15265/18065

19. Figueiredo SV, Sousa ACC, Gomes ILV. Children with special health needs and family: implications for Nursing. Rev Bras Enferm. 2016; 69(1):79-85. doi: dx.doi.org/10.1590/0034-7167.2016690112i

20. Costa NR, Marcelino MA, Duarte CMR, Uhr D. Social protection and people with disabilities in Brazil. Ciênc Saúde Coletiva. 2016; 21(10):303747. doi: http://dx.doi.org/10.1590/1413812320152110.18292016 